\title{
Anthophysa vegetans (O.F. Müller) Stein (Chrysophyceae), a new record from South Africa
}

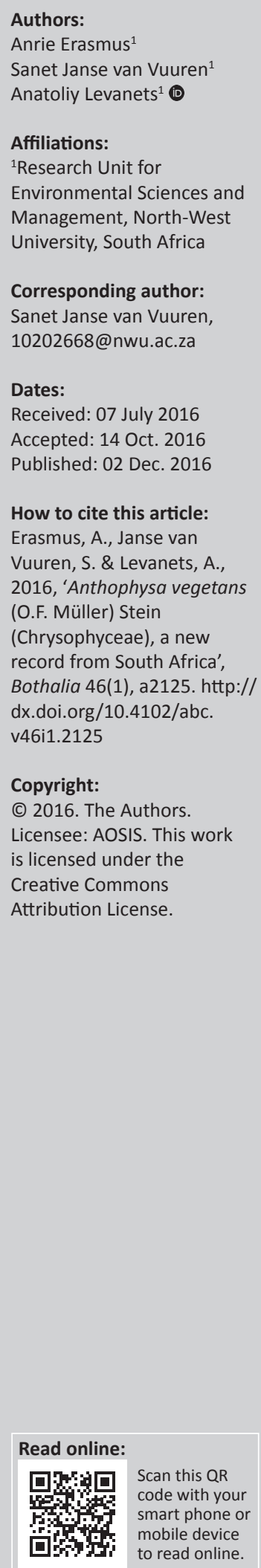

Background: Although the colonial flagellate alga Anthophysa vegetans is well known in Europe, it has only been recorded from Africa (Nigeria) once. It was recently found in the Mooi River, South Africa - making this a first record of the presence of A. vegetans in southern Africa.

Objectives: The objective of this study is to record a new geographic locality for A. vegetans for South Africa.

Method: Light microscopy was used to compare morphological features of the species found in South Africa with illustrations and literature on A. vegetans found in Europe and other countries of the world. An extensive literature survey was done to determine the species' current geographic distribution.

Results: A. vegetans is widely distributed across all continents, except Africa and Antarctica. During this study, it was described from a new location in the Mooi River near Potchefstroom in the North West province, South Africa, making this a first record of its presence in southern Africa.

Conclusion: The known geographic distribution of $A$. vegetans was expanded to include southern Africa and, to be more specific, South Africa.

\section{Introduction}

During 1702, Antonie van Leeuwenhoek first observed the colourless, flagellate colonial algal genus Anthophysa Bory de Saint-Vincent 1822 (Dobell 1932). It was originally described as Volvox vegetans in Otto Frederik Müller's 'Animalcula Infusioria' during 1786. The genus name Anthophysa Bory de Saint-Vincent (1822) was later erected for this 'apparently' stalked species resembling Volvox. At the same time as introducing this new genus, Bory de Saint-Vincent (1822) changed the specific name from vegetans to muelleri in honour of Müller. This name is superfluous, and the change was subsequently reversed by Stein (1878). Bory de Saint-Vincent (1822) included a second Anthophysa species, A. dichotoma, in his 1822 work and subsequently added a third, A. solitaria, with the briefest of detail and no illustrations.

Today, the genus is often interpreted as being monospecific (Preisig et al. 1991; Starmach 1985), although there is still much confusion and different points of view (Guiry \& Guiry 2016; Hänel 1979). According to the Algaebase database (Guiry \& Guiry 2016), Anthophysa is a small genus with ten species names currently recorded, although only six of these have been flagged as currently accepted species.

Anthophysa vegetans is well documented from all continents, except Africa, where it has been recorded only once in the Jakara Dam in Nigeria (Abubakar \& Abdullahi 2015), and Antarctica with no known record. Unidentified members of the genus Anthophysa were recorded in the Klip River, South Africa, by Hancock (1973), as well as in and around Kirstenbosch National Botanical Garden in Cape Town by Joska et al. (2005). No record could, however, be found on the presence of $A$. vegetans in southern Africa.

\section{Research method and materials Materials}

Freshwater samples were collected during routine sampling from January 2014 to April 2015 at four sampling sites located along a 25-km stretch of the Mooi River system near Potchefstroom in the North West province, South Africa (Figure 1). At each site, a 100-ml grab sample was taken, and the unpreserved samples were left overnight to be examined the next day. 


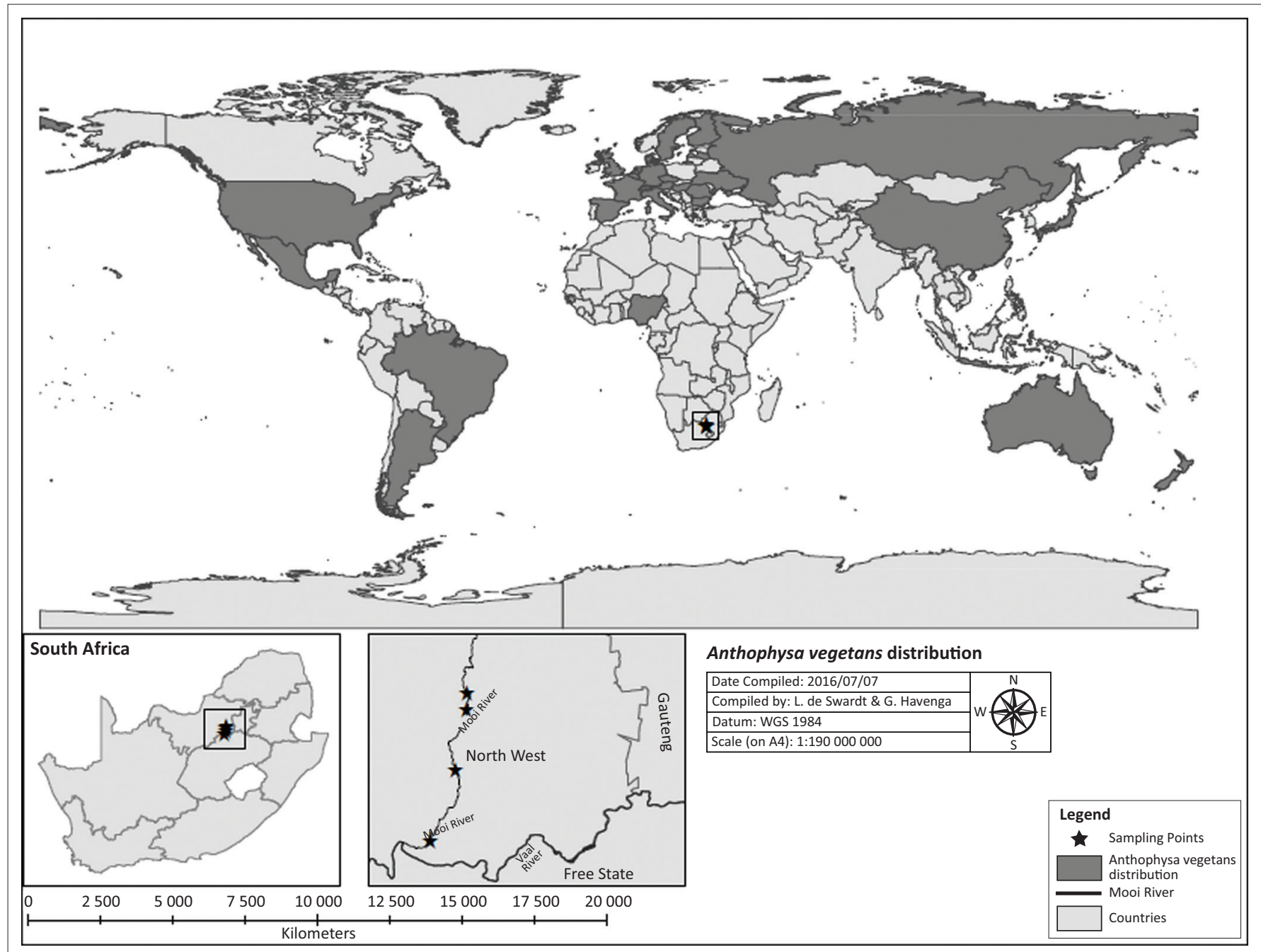

Source: Compiled by Carthographic Services, School of Geo- and Spatial Sciences, North-West University, Potchefstroom

FIGURE 1: Current known distribution of Anthophysa vegetans.

\section{Procedures}

Sub-samples were transferred to an Utermohl sedimentation chamber. Algae were identified to species level with an inverted Zeiss light microscope. Literature consulted for identification of $A$. vegetans includes Belcher and Swale (1972), Starmach (1985), Lee and Kugrens (1989) and Baker (2012). Measurements of cell and colony sizes were made by means of a ruler in one of the eyepieces of the microscope.

\section{Taxonomic treatment}

Anthophysa vegetans (O.F. Müller) Stein in Der Organismus der Infusionthiere nach eigenen Forschungen in Systematischer Reihenfolge bearbeitet. I Hälfte: 36, legend to pl. V [5]: 1, 1' (1878). Basionym: Volvox vegetans O.F. Müller in Animalcula infusoria fluviatilia et marina quæ detexit: 22, pl. III [3]: figs 22-25 (1786). Synonym: Anthophysa muelleri Bory, nom. illeg. superfl., in Dictionnaire Classique d'Histoire Naturelle. 1: 427, 597 (1822).

Type: DENMARK, in freshwaters, November 1779 and 1780, illustration in Müller in Animalcula infusoria fluviatilia et marina quæ detexit: 22, pl. III [3], figs 22-25 (1786).

\section{Description}

Attachment of Anthophysa colonies is by means of an inorganic stalk (Figure 2) that becomes encrusted with deposits of calcium phosphate and precipitates of iron and manganese (Baker 2012; Misner 2009). In Pringsheim (1946), the morphology and development of the stalk is described and specific reference is made to its dependence upon soluble iron and manganese compounds. The mineralised stalk is often branched (Guiry \& Guiry 2016) and is the species' most valuable diagnostic feature (Figure 2). Stalks vary greatly in diameter, increasing towards the base (Belcher \& Swale 1972) and are brownish in colour, though the colour is dependent on the age and the mineral composition of the stalk. Lee and Kugrens (1989) found that the addition of $\mathrm{FeCl}_{3}$ resulted in yellow stalks, while the addition of $\mathrm{MnCl}_{2}$ resulted in dark orange-brown stalks. Bacteria are usually visible on the stalks. Belcher and Swale (1972) speculated that the origin of the stalks was mucilage secretions of the Anthophysa cells.

Spherical or hemispherical colonies (Belcher \& Swale 1972) can be found on top of the stalks and these, as well as individual cells, are capable of separating themselves from 


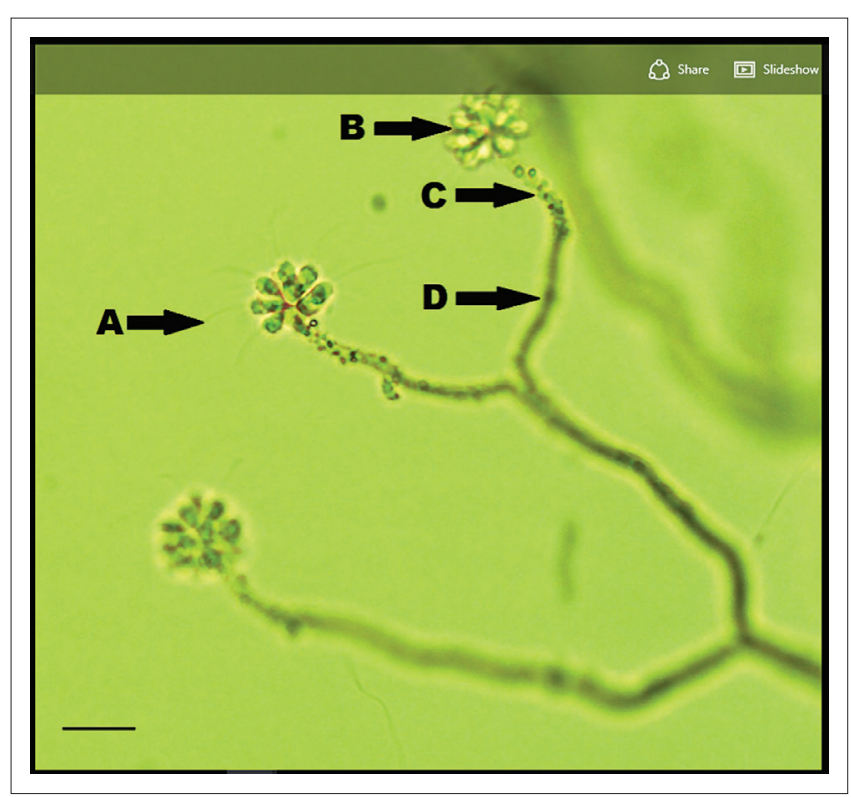

Source: Photograph taken by authors at the North-West University, Potchefstroom FIGURE 2: Light microscope image of Anthophysa vegetans. Diagnostic features are indicated with arrows. A: Flagella, B: Colony with cells, C: Precipitates of iron and manganese, D: Branched stalks; Scale bar $=25 \mu \mathrm{m}$.

the stalks and becoming fixed to commence new colony formation. Colonies can swim freely, with a rolling motion similar to that performed by Volvox (Clark 1866). The number of individuals forming a colony ranges from 2 to 50 (Clark 1866).

The small $(7-10 \times 5-7 \mu \mathrm{m})$, colourless cells within the colonies are obpyriform or obconical (Belcher \& Swale 1972), that is, wide at the anterior end, narrowing towards the posterior end (Figure 2). Food is taken in at one side of the anterior end in a gullet-like furrow. Each cell has two unequal flagella situated next to the furrow where food is taken in. The long flagellum is slightly curved (Figure 2) and usually body length (but not longer than $30 \mu \mathrm{m}$ ) and contains two rows of tripartite hairs. The second, short and delicate flagellum, usually half of the body length (maximum length of $5 \mu \mathrm{m}$ ), has a smooth surface (Belcher \& Swale 1972). The short flagellum is situated at a right angle to the long flagellum. The long flagellum can be used to propel the cell forward. Food is obtained by phagotrophy or through the oxidation of organic substances (chemo-organotrophy, Belcher \& Swale 1972).

\section{Distribution and ecology}

According to Belcher and Swale (1972) A. vegetans is widely distributed, and literature searches revealed its presence in the freshwaters of most continents, including Europe, Asia, North and South America, and Australia (Figure 1). In Africa, it has been recorded only once before, in the Jakara Dam in Nigeria by Abubakar and Abdullahi (2015). No records could be found of this species' presence south of Nigeria on the African continent. Anthophysa is commonly found in freshwater systems that contain high concentrations of iron and manganese that precipitate in the stalks (Pringsheim 1952; Starmach 1985). The Mooi River in North
West province, South Africa, where the species was collected, receives contamination from a wide variety of point and diffuse sources. The Wonderfonteinspruit, a tributary of the Mooi River, flows through the richest gold mining region in the world and has been exposed to pollution for more than a century (Hamman \& Van Rensburg 2012). Large-scale mining, together with storm water, and effluent from several urban and industrial areas, as well as informal settlements, contaminate the water (Van der Walt et al. 2002). Contaminants include heavy metals such as iron and manganese (Hamman \& Van Rensburg 2012). Increased levels of heavy metals were also reported from the sediments of the Mooi River (Wade et al. 2000).

\section{New record}

SOUTH AFRICA. North West province: Mooi River near Potchefstroom, 263' $12.25^{\prime \prime}$ S, $27^{\circ} 7^{\prime} 31.81^{\prime \prime}$, 14 January 2014, De Wet 1 (PUC), (Figure 2).

\section{Conclusion}

Anthophysa vegetans has now been recorded for the first time in southern Africa, in the Mooi River in the North West province, South Africa. This represents an expansion of the known geographic distribution of this species. The presence of Anthophysa vegetans in the Mooi River may be linked to iron and manganese pollution, as these metals are known to be incorporated into its stalks.

\section{Acknowledgements}

The authors would like to thank Prof. S. Barnard and Dr. A. Venter for providing funding for the project.

\section{Competing interest}

The authors declare that they have no financial or personal relationship(s) which may have inappropriately influenced them in writing this article.

\section{Authors' contributions}

A.E. found the specimen in the samples, S.J.v.V. identified the specimen and A.L. did the literature research. S.J.v.V. and A.L. co-wrote the article.

\section{References}

Abubakar, A. \& Abdullahi, B.A., 2015, 'Flora composition of phytoplankton as bioindicators of water quality in Jakara Dam, Kano State, Nigeria', Bayero Journal of Pure and Applied Science 8(2), 145-155. http://dx.doi.org/10.4314/bajopas. v8i2.25

Baker, A.L., 2012, Phycokey - An image based key to Algae (PS Protista), Cyanobacteria, and other aquatic objects, Center for Freshwater Biology, University of New Hampshire, viewed 6 May 2016, from http://cfb.unh.edu/phycokey/phycokey. htm

Belcher, J.H. \& Swale, E.M.F., 1972, 'The morphology and fine structure of the colourless colonial flagellate Anthophysa vegetans (O.F. Muller) Stein', British Phycological Bulletin 7(3), 335-346. http://dx.doi.org/10.1080/00071617200 650351

Bory de Saint-Vincent, J.B.M., 1822, Dictionnaire Classique d'Histoire Naturelle, Rey et Gravier, Libraries-Editeurs, Auai des Augustins, no. 55; Baudouin Frèrer Libraries-Editeurs, Imprimeurs de la société D'Histoire Naturelle, Rue de Vaugirard, no. 36, Paris. 
Clark, H.J., 1866, 'On the structure and habits of Anthophysa mulleri Bory, one of the sedentary monadiform Protozoa', The Annals and Magazine of Natural History sedentary monadiform Protozoa', The Annals and Magazine
18-436. http://dx.doi.org/10.2475/ajs.s2-42.125.223

Dobell, C., 1932, Antony van Leeuwenhoek and his 'Little Animals', Constable, London.

Guiry, M.D. \& Guiry, G.M., 2016, AlgaeBase, National University of Ireland, Galway, viewed 5 May 2016, from http://www.algaebase.org

Hamman, D. \& Van Rensburg, L., 2012, 'The transfer and accumulation of trace metals from the Wonderfonteinspruit into the surrounding environment', in D.W. Pepper \& C.A. Brebbia (eds.), Water and Society, pp. 209-219, WIT Press, Ashurst, United Kingdom.

Hancock, F.D., 1973, 'Algal ecology of a stream polluted through gold mining on the Witwatersrand', Hydrobiologia 43, 189-229. http://dx.doi.org/10.1007/BF0001 4267

Hänel, K., 1979, 'Systematics and ecology of colourless flagellates in sewage', Archiv fur Protistenkunde 121, 73-137. http://dx.doi.org/10.1016/S0003-9365(79) 80010-X

Joska, M.A.P., Day, J.A., Boulle, J. \& Archibald, S., 2005, Development of a biomonitoring method using protozoans for assessment of water quality in rivers and ground waters and seasonal/ephemeral waters, Water Research Commission Report No.: 1017/1/05, Water Research Commission, Pretoria, South Africa.

Lee, R.E. \& Kugrens, P., 1989, 'Biomineralization of the stalks of Anthophysa vegetans (Chrysophyceae)', Journal of Phycology 25, 591-596. http://dx.doi.org/10.1111/j. 1529-8817.1989.tb00265.x

Misner, I., 2009, 'Morphological \& phylogenetic analysis of two species of heterokont algae, Master of science thesis, University of North Carolina, Wilmington, DE.
Müller, O.F., 1786, Animalcula infusoria fluviatilia et marina quae detexit, systematice descripsit et ad vivum delineari curavit Otho Fridericus Müller; sistet opus hoc posthumum, quod cum tabulis Aeneis L. in lucem tradit vidua ejus nobilissima cura Othonis Fabricii, pp. i-vi, 1-367, Hauniae, Copenhagen, Denmark.

Preisig, H.R., Vørs, N. \& Hällfors, G., 1991, 'Diversity of heterotrophic heterokonts', in D.J. Patterson \& J. Larsen (eds.), The biology of free-living heterotrophic flagellates, pp. 361-339, Clarendon Press, Oxford.

Pringsheim, E.G., 1946, 'On iron flagellates', Philosophical Transactions of the Royal Society London Series B 232, 311-342. http://dx.doi.org/10.1098/rstb.1946. 0004.s

Pringsheim, E.G., 1952, 'On the nutrition of Ochromonas', Journal of Microscopical Science 93, 71-96.

Starmach, K., 1985, 'Chrysophyceae und Haptophyceae', in H. Ettle, J. Gerloff, H. Heynig \& D. Mollenhauer (eds.), Süsswasserflora von Mitteleuropa, Band 1, pp. 1-515, Gustav Fischer Verlag, Stuttgart, Germany.

Stein, F.V., 1878, Der Organismus der Infusionsthiere nach eigenen Forschungen in Systematischer Reihenfolge bearbeitet. I Hälfte, pp. i-x, 1-154, plates I-XXIV, Verlag von Wilhelm Engelmann, Leipzig, Germany.

Van der Walt, I.J., Winde, F. \& Nell, B., 2002, 'Integrated catchment management: The Mooi River (Northwest Province, South Africa) as a case study', Cuadernos de Investigación Geográfica 28, 109-126. http://dx.doi.org/10.18172/cig.1131

Wade, P.C., Woodborne, S., Morris, W.M., Vos, P. \& Jarvis, N.V., 2000, Risk assessment of selected radionuclides in sediment of the Mooi River catchment, Water Research Commission Report No. K5/1059, Water Research Commission, Pretoria, South Africa. 